\title{
RANCANGAN APLIKASI LAYANAN PAJAK KENDARAAN BERMOTOR PADA DISPENDA
}

\author{
Fakultas Teknologi Informasi \\ Universitas Islam Kalimantan Muhammad Arsyad Al Banjari Banjarmasin \\ Haji Sirajuddin \\ Uniska.siraj@gmail.com
}

\begin{abstract}
Sistem Administrasi Manunggal Satu Atap (disingkat Samsat), atau dalam bahasa Inggris One Roof System adalah suatu sistem administrasi yang dibentuk untuk memperlancar dan mempercepat pelayanan kepentingan masyarakat yang kegiatannya diselenggarakan dalam satu gedung. Contoh dari samsat adalah dalam pengurusan dokumen kendaraan bermotor. Penelitian ini bertujuan untuk mempermudah Proses Pemesanan dan Pencetakan Tanda Nomor Kendaraan Bermotor (TNKB) Banjarmasin dan memberikan kemudahan kepada Wajib Pajak Kendaraan Bermotor dalam memperoleh informasi dan pelayanan cepat yang sedang dibutuhkan. Dalam penelitian ini, kami menggunakan Visual Foxpro 9.0 sebagai bahasa pemrogramannya dan sebagai database nya kami menggunakan MySQL .
\end{abstract}

Kata kunci : MySQL, Visual Foxpro.

\section{PENDAHULUAN}

Pelayanan terhadap masyarakat merupakan suatu penilaian penting dari masyarakat terhadap Instansi Pemerintah. Sistem Administrasi Manunggal Satu Atap (disingkat Samsat), atau dalam bahasa Inggris One Roof System adalah suatu sistem administrasi yang dibentuk untuk memperlancar dan mempercepat pelayanan kepentingan masyarakat yang kegiatannya diselenggarakan dalam satu gedung. Contoh dari samsat adalah dalam pengurusan dokumen kendaraan bermotor. Dimana sekarang ini Samsat Banjarmasin berupaya untuk memperbaiki kualitas pelayanan yang sebelumnya secara manual, sekarang salah satu usaha yang dilakukan adalah dengan menggunakan komputer dalam melakukan Sistem administrasi pemesanan TNKB (Tanda Nomor Kendaraan Bermotor). Sasaran yang diinginkan adalah waktu proses order, pembuatan, dan penyampaian TNKB sesuai yang diinginkan wajib pajak yaitu menjadi lebih cepat dan tepat. Untuk masalah pemesanan Tanda Nomor Kendaraan Bermotor (TNKB). Aplikasi ini diharapkan membantu wajib pajak dalam melakukan aktivitas pemesanan TNKB, di mana dalam aplikasi ini wajib pajak tidak perlu menunggu lama di bagian pencetakan (workshop) tanda nomor kendaraan bermotor untuk memesan TNKB, aplikasi ini akan memberikan kemudahan dalam melakukan pemesanan Tanda Nomor Kendaraan Bermotor.

\section{RUMUSAN MASALAH}

Berdasarkan uraian latar belakang, maka permasalahan yang dapat dikaji dalam penelitian ini adalah : Penulis menitik beratkan pada bagian Pemesanan Tanda Nomor Kendaraan Bermotor (TNKB) pada UPPD/ Samsat Banjarmasin 


\section{TUJUAN PENELITIAN}

Penelitian ini bertujuan untuk membuat rancangan Aplikasi Layanan Pajak Kendaraan Bermotor Pada Dispenda Banjarmasin Khususnya tentang Tanda Nomor Kendaraan Bermotor (TNKB) dalam suatu kelompok database dengan menggunakan suatu perangkat lunak. Dalam penelitian ini kami menggunakan perangkat lunak Visual Foxpro 9.0 dan MySQL.

\section{TARGET LUARAN DAN MANFAAT PENELITIAN}

Target luaran dalam pembuatan laporan penelitian ini yaitu bisa masuk ke Jurnal UNISKA kemudian bisa dilanjutkan ke Jurnal Nasional . Sedangkan Manfaat yang diharapkan yaitu : dengan adanya penelitian ini Aplikasi ini diharapkan membantu wajib pajak dalam melakukan aktivitas pemesanan TNKB, di mana dalam aplikasi ini wajib pajak tidak perlu menunggu lama di bagian pencetakan (workshop) tanda nomor kendaraan bermotor untuk memesan TNKB, aplikasi ini akan memberikan kemudahan dalam melakukan pemesanan Tanda Nomor Kendaraan Bermotor.

\section{METODE PENELITIAN}

Pada dasarnya Informasi yang ada sudah menggunakan komputer dan perangkat pendukung lainnya. Namun pada bagian Sistem pemesanan TNKB di UPPD/Samsat Banjarmasin selama ini masih menerapkan sistem secara manual atau dengan kata lain masih menggunakan kertas arsip sebagai penyerahan data. $m$ penelitian ini kami menggunakan perangkat lunak Visual Foxpro 9.0 dan MySQL.

\section{Perancangan Database}

Dalam pembuatan suatu sistem yang baik diperlukan perancangan database yang baik. Database sebagai tempat penyimpanan data merupakan salah satu aspek penting yang akan menentukan mutu kerja data program yang dibuat. Perancangan sebuah database berdasarkan bagaimana cara merancang dari sistematika proses dari sistem tersebut. Pada umumnya database telah disiapkan untuk menghasilkan sebuah laporan informasi tertentu yang dikehendaki.

\section{Rancangan Input ( Form )}

Pada rancangan masukan ini terdiri dari beberapa file program, yaitu program masukan, keluaran serta beberapa program pendukung lainnya.

Adapun rancangan masukan yang dimaksud adalah sebagai berikut :

a. Program Entry Data Pemesanan Tanda Nomor kendaraan Bermotor (TNKB)

Program entry data ini adalah program untuk merekam nopol, tanggal pesan beserta item lainnya. Proses perekaman data dikontrol dengan menggunakan item nopol dan tanggal pesan sebagai field key untuk mencegah terjadinya duplikasi data yang sama. nopol dan item lainnya tersebut dimasukkan dan direkam pada sebuah file database Tabel Pesan.

b. Program Entry Data Pencetakan / workshop Tanda Nomor kendaraan Bermotor (TNKB)

Program entry data ini adalah program untuk merekam nopol, tanggal cetak beserta item lainnya. Proses perekaman data dikontrol dengan menggunakan item nopol dan tanggal cetak sebagai field key untuk mencegah terjadinya duplikasi data yang sama. nopol dan item lainnyatersebut dimasukkan dan direkam pada sebuah file database Tabel Cetak.

\section{Rancangan Output (Report)}

Rancangan keluaran dalam penelitian ini berupa rancangan di layar monitor (screen) dan cetakan ke printer. Untuk media keluaran dapat ditentukan melalui 
suatu menu pilihan. Ada dua menu pilihan, yaitu menampilkan data ke display atau mencetak ke media kertas melalui printer.

\section{Rancangan File}

perangkat yang dirancang ini menggunakan beberapa buah file database yang saling berelasi antara satu dengan yang lainnya denggan menggunakan field key dari masingmasing file database.

Tabel Rancangan File Koneksi

\begin{tabular}{|l|l|l|l|}
\hline Name & Type & $\begin{array}{l}\text { Wid } \\
\text { th }\end{array}$ & Index \\
\hline $\begin{array}{l}\text { kd_lok } \\
\text { asi }\end{array}$ & $\begin{array}{l}\text { Chara } \\
\text { cter }\end{array}$ & 3 & $\begin{array}{l}\text { Ascend } \\
\text { ing }\end{array}$ \\
\hline $\begin{array}{l}\text { ip_ser } \\
\text { ver }\end{array}$ & $\begin{array}{l}\text { Chara } \\
\text { cter }\end{array}$ & 15 & \\
\hline $\begin{array}{l}\text { Namad } \\
\text { b }\end{array}$ & $\begin{array}{l}\text { Chara } \\
\text { cter }\end{array}$ & 40 & \\
\hline $\begin{array}{l}\text { Userna } \\
\text { me }\end{array}$ & $\begin{array}{l}\text { Chara } \\
\text { cter }\end{array}$ & 40 & \\
\hline Pass & $\begin{array}{l}\text { Chara } \\
\text { cter }\end{array}$ & 40 & \\
\hline
\end{tabular}

Digunakan untuk menyimpan informasi tempat/ lokasi, hostname, nama database, user dan password database yang digunakan, bisa untuk satu database atau lebih.

Tabel Rancangan FileLogin

\begin{tabular}{|l|l|l|l|}
\hline Name & Type & $\begin{array}{l}\text { Wid } \\
\text { th }\end{array}$ & Index \\
\hline $\begin{array}{l}\text { Userna } \\
\text { me }\end{array}$ & $\begin{array}{l}\text { Chara } \\
\text { cter }\end{array}$ & 25 & $\begin{array}{l}\text { Ascend } \\
\text { ing }\end{array}$ \\
\hline Login & $\begin{array}{l}\text { Chara } \\
\text { cter }\end{array}$ & 10 & \\
\hline
\end{tabular}

Digunakan untuk menyimpan informasi pengguna Aplikasi : Nama dan Sandi untuk bisa akses ke aplikasi.

Tabel Rancangan FileCetak

\begin{tabular}{|l|l|l|l|}
\hline Name & Type & $\begin{array}{l}\text { Wid } \\
\text { th }\end{array}$ & Index \\
\hline $\begin{array}{l}\text { tgl_ceta } \\
\mathrm{k}\end{array}$ & $\begin{array}{l}\text { Chara } \\
\text { cter }\end{array}$ & 10 & $\begin{array}{l}\text { Ascen } \\
\text { ding }\end{array}$ \\
\hline
\end{tabular}

\begin{tabular}{|l|l|l|l|}
\hline $\begin{array}{l}\text { no_poli } \\
\text { si }\end{array}$ & $\begin{array}{l}\text { Chara } \\
\text { cter }\end{array}$ & 12 & $\begin{array}{l}\text { Ascen } \\
\text { ding }\end{array}$ \\
\hline $\begin{array}{l}\text { nm_pe } \\
\text { milik }\end{array}$ & $\begin{array}{l}\text { Chara } \\
\text { cter }\end{array}$ & 35 & \\
\hline $\begin{array}{l}\text { bln_th_ } \\
\text { plat }\end{array}$ & $\begin{array}{l}\text { Chara } \\
\text { cter }\end{array}$ & 5 & \\
\hline $\begin{array}{l}\text { Warna_- } \\
\text { plat }\end{array}$ & $\begin{array}{l}\text { Chara } \\
\text { cter }\end{array}$ & 6 & \\
\hline $\begin{array}{l}\text { No_ran } \\
\text { gka }\end{array}$ & $\begin{array}{l}\text { Chara } \\
\text { cter }\end{array}$ & 20 & \\
\hline $\begin{array}{l}\text { No_mes } \\
\text { in }\end{array}$ & $\begin{array}{l}\text { Chara } \\
\text { cter }\end{array}$ & 20 & \\
\hline $\begin{array}{l}\text { No_daft } \\
\text { ar }\end{array}$ & $\begin{array}{l}\text { Chara } \\
\text { cter }\end{array}$ & 20 & \\
\hline $\begin{array}{l}\text { Masa_la } \\
\text { ku }\end{array}$ & $\begin{array}{l}\text { Chara } \\
\text { cter }\end{array}$ & 10 & \\
\hline $\begin{array}{l}\text { Status_c } \\
\text { etak }\end{array}$ & $\begin{array}{l}\text { Chara } \\
\text { cter }\end{array}$ & 1 & \\
\hline $\begin{array}{l}\text { Kd_lok } \\
\text { asi }\end{array}$ & $\begin{array}{l}\text { Chara } \\
\text { cter }\end{array}$ & 3 & \\
\hline
\end{tabular}

Digunakan untuk menyimpan informasi data TNKB

yang sudah dicetak.

Tabel Rancangan File statuscetak

\begin{tabular}{|l|l|l|l|}
\hline Name & Type & $\begin{array}{l}\text { Wid } \\
\text { th }\end{array}$ & Index \\
\hline $\begin{array}{l}\text { Kd_sta } \\
\text { tus }\end{array}$ & $\begin{array}{l}\text { Chara } \\
\text { cter }\end{array}$ & 1 & $\begin{array}{l}\text { Ascend } \\
\text { ing }\end{array}$ \\
\hline $\begin{array}{l}\text { Ket_st } \\
\text { atus }\end{array}$ & $\begin{array}{l}\text { Chara } \\
\text { cter }\end{array}$ & 12 & \\
\hline
\end{tabular}

Digunakan untuk menyimpan informasi Status Cetak TNKB. Dipakai untuk memfilter / menyaring laporan yang belum cetak dan sudah cetak.

\section{ANALISA HASIL DAN \\ PEMBAHASAN \\ Hasil Penelitian}

Adapun tampilan dan keluaran dari Aplikasi Pemesanan Tanda Nomor Kendaraan Bermotor (TNKB) Menggunakan Visual Foxpro 9.0 adalah Sebagai berikut:

\section{Tampilan Form LOGIN}

Jurnal Ilmiah Fakultas Teknik "Technologia" 


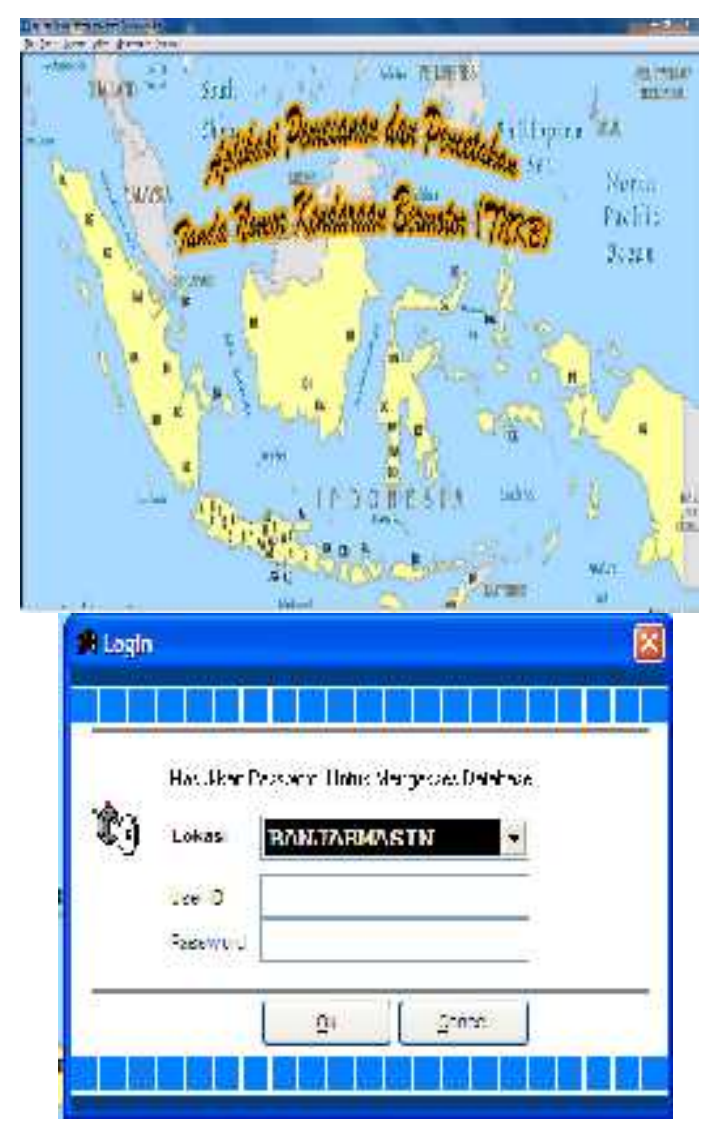

Gambar Tampilan Form LOGIN

Form LOGIN berfungsi untuk Pemilihan daerah / lokasi pemesanan, menginputkan User ID dan Password yang sudah ditentukan yang berfungsi untuk masuk ke form Menu Utama. Adapun komponen properties pada tampilan Form LOGIN, adalah Sebagai berikut:

2. Tampilan Menu Utama

\section{Gambar Tampilan Form Menu Utama}

Form Menu Utama merupakan form master atau induk dari dimana didalamnya terdapat menu pull-down yang dapat digunakan untuk membuka form-form yang lainnya.Adapun komponen properties pada tampilan Form Menu Utama, adalah Sebagai berikut:

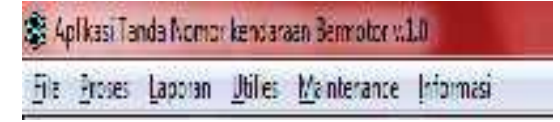

3. Tampilan Daftar Wajib Pajak

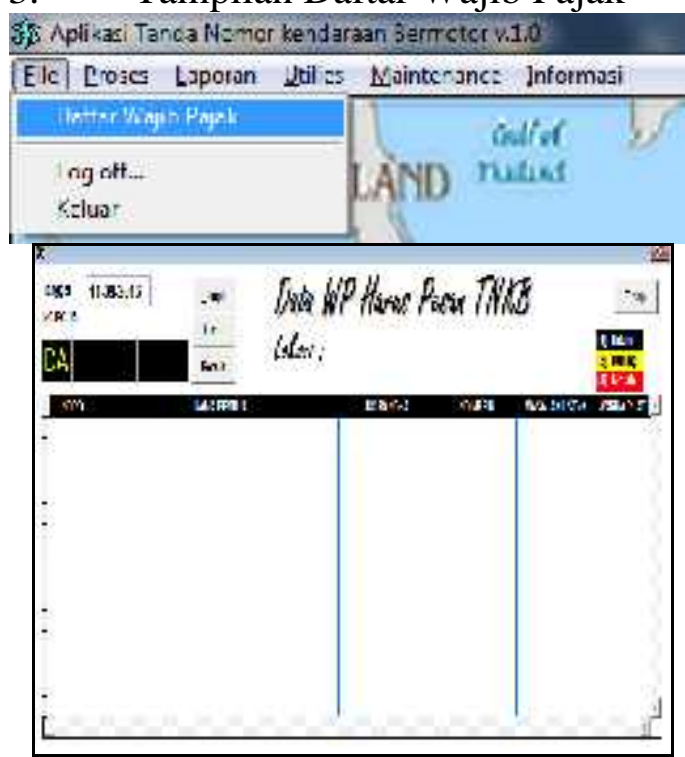

\section{Gambar Tampilan Form Daftar Wajib Pajak}

Form ini berfungsi untuk menampilkan Data Wajib Pajak yang berpotensi untuk melakukan pemesanan dan pencetakan TNKB dimana didalamnya terdapat Nopol (Primary Key), Nama Pemilik, No.Rangka, No.Mesin, Masalaku STNK Dan Warna TNKB/ Plat yang dicetak. Sehingga dengan adanya Nopol (Primary Key), maka pencarian data dapat dilakukan dengan cepat.

Adapun komponen properties pada tampilan Form Daftar Wajib Pajak, adalah Sebagai berikut:

\section{Tampilan Form Pemesanan TNKB}

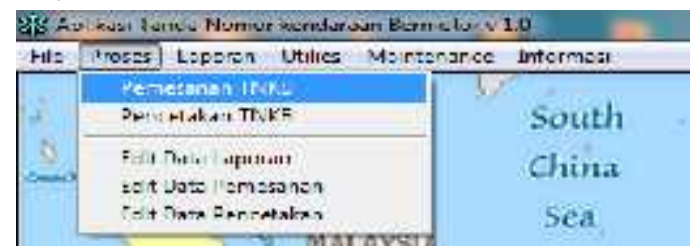




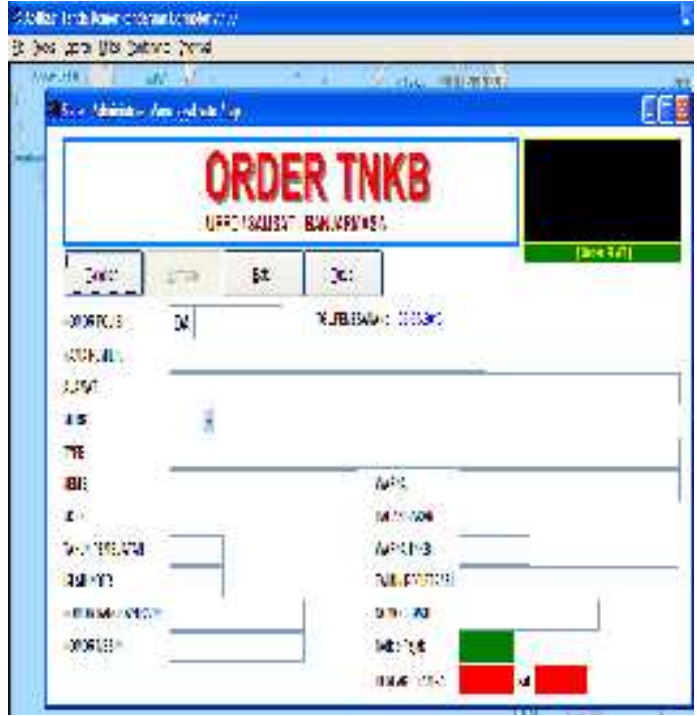

\section{Gambar Tampilan Form Pemesanan TNKB}

Form ini berfungsi untuk menginputkan atau memanggil data wajib pajak yang harus pesan dimana didalamnya terdapat Nomor Polisi (Primary Key), Nama Pemilik, Alamat Pemilik, Merk, Type, Jenis, Model, Tahun Buat, Silinder, No.Rangka, No.Mesin, Warna KB, Bahan Bakar, Warna TNKB, Masalaku Pajak dan Masalaku STNK. Sehingga dengan adanya Nomor Polisi (Primary Key), maka pencarian data dapat dilakukan dengan cepat.

Adapun komponen properties pada tampilan Form Pemesanan TNKB, adalah Sebagai berikut:

5. Tampilan Form Pencetakan

\section{TNKB}

\begin{tabular}{|c|c|c|c|c|}
\hline \multicolumn{5}{|c|}{ 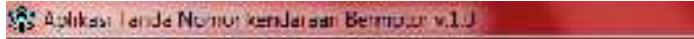 } \\
\hline File & Ficses Lapcran Utile: & Ya ntenance & Jaformasi & \\
\hline \multicolumn{5}{|c|}{ Femesor:- TTIKR } \\
\hline \multirow{4}{*}{ indo } & FernestakanTाK & & South & $.11 \Rightarrow$ \\
\hline & [dit Deza L:sorar & & Chin & \\
\hline & F-tit Jon Temesar:- & & 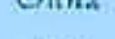 & \\
\hline & EJit $D=\Delta \mathrm{Fu}$ idda:=1 & & Sea & \\
\hline
\end{tabular}

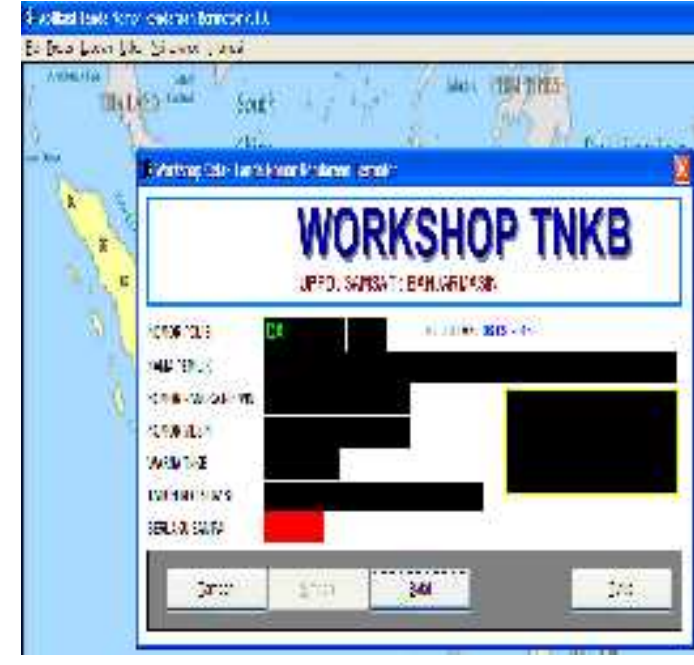

\section{Gambar Tampilan Form Pencetakan TNKB}

Form ini berfungsi untuk Memanggil Data yang sudah pesan TNKB didalamnya terdapat Nomor Polisi (Primary Key), Nama Pemilik, No.rangka, No.Mesin, Warna TNKB, Tahun Registrasi, Tanggal Cetak dan masalaku. Sehingga dengan adanya Nomor Polisi (Primary Key), maka pencarian data dapat dilakukan dengan cepat. Adapun komponen properties pada tampilan Form Pencetakan TNKB, adalah Sebagai berikut:

\section{Tampilan Form Laporan}

\section{BELUM Cetak TNKB}

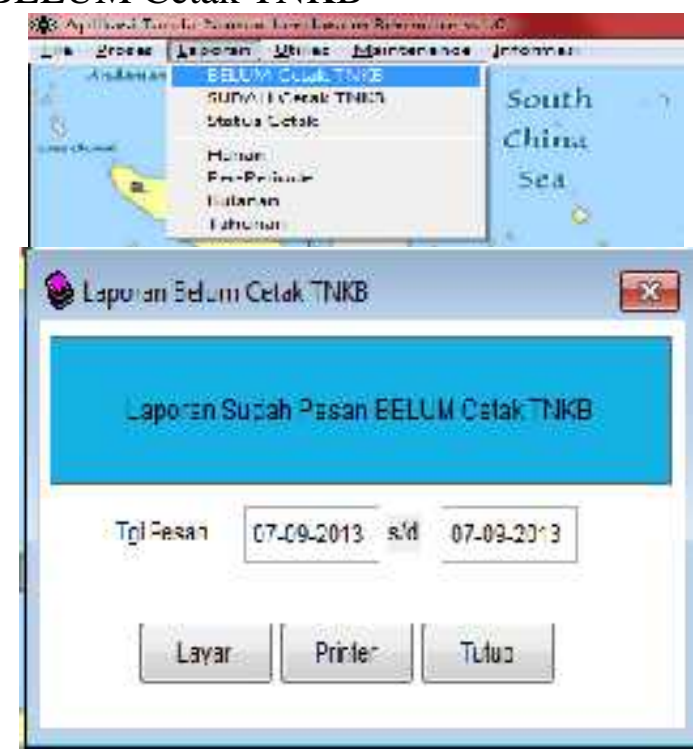




\section{Gambar Tampilan Form Cetak Laporan Belum Cetak TNKB}

Form ini berfungsi untuk menampilkan output laporan berdasarkan tanggal awal dan tanggal akhir yang dipilih. Adapun komponen properties pada tampilan Form Cetak Laporan Sudah Pesan Belum Cetak TNKB, adalah Sebagai berikut:

7. Tampilan Form Laporan SUDAH Cetak TNKB

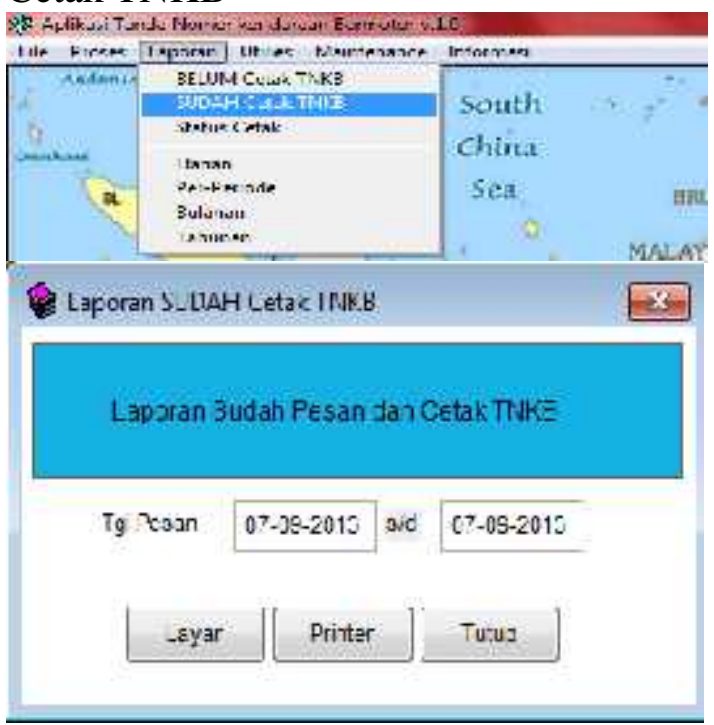

\section{Gambar Tampilan Form Cetak} Laporan Sudah Cetak TNKB

Form ini berfungsi untuk menampilkan output laporan berdasarkan Textbox yang dipilih.

8. Tampilan Form Status Cetak

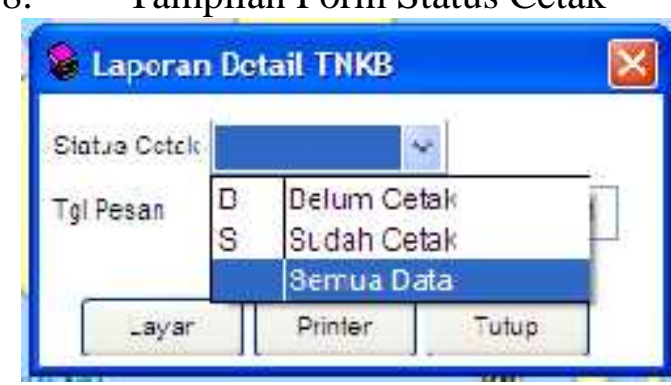

\section{Gambar Tampilan Form Status Cetak}

Form ini berfungsi untuk mencek atau mengetahui status berkas berdasarkan combobox yang dipilih dengan memilih terlebih dahulu status yang ditentukan.
Adapun komponen properties pada tampilan Form Status Cetak, adalah Sebagai berikut:

9. Tampilan Form Laporan Harian

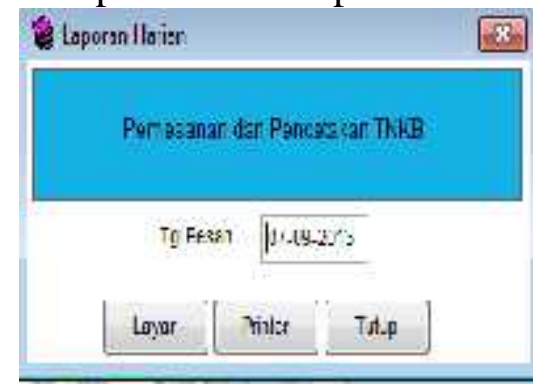

\section{Gambar Tampilan Form Laporan Harian}

Form ini berfungsi untuk menampilkan output laporan Harian berdasarkan Command Button yang dipilih dengan menginputkan terlebih dahulu Tanggal Pesan. Adapun komponen properties pada tampilan Form Cetak Laporan Harian, adalah Sebagai berikut:

10. Tampilan Form Laporan Per-

Periode

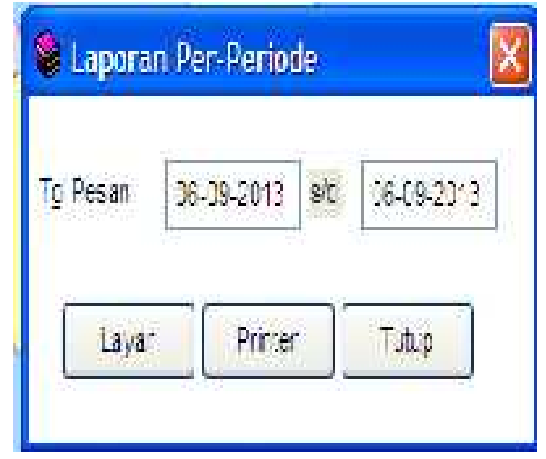

\section{Gambar Tampilan Form Laporan Per-Periode}

Form ini berfungsi untuk menampilkan output laporan Harian berdasarkan Command Button yang dipilih dengan menginputkan terlebih dahulu Tanggal Pesan awal dan tanggal Pesan Akhir. Adapun komponen properties pada tampilan Form Cetak Laporan Perperiode, adalah Sebagai berikut:

11. Tampilan Form Laporan Bulanan 


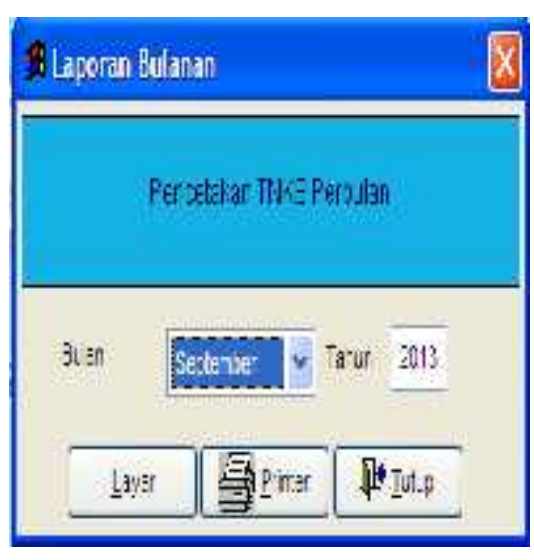

\section{Gambar Tampilan Form Laporan Bulanan}

Form ini berfungsi untuk menampilkan output laporan Bulanan berdasarkan Combo Button yang dipilih dan Textbox yang di isikan tahun. Adapun komponen properties pada tampilan Form Cetak Laporan Bulanan, adalah Sebagai berikut:

12. Tampilan Form Laporan Tahunan

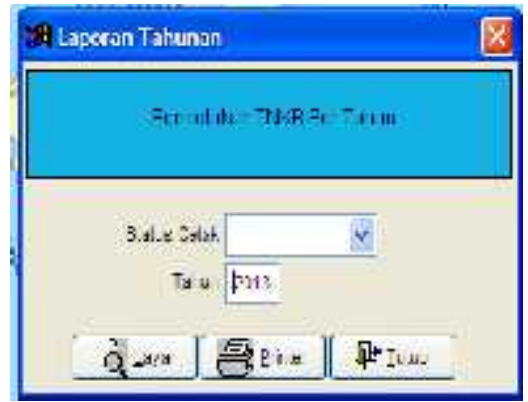

\section{Gambar Tampilan Form Laporan Tahunan}

Form ini berfungsi untuk menampilkan output laporan Tahunan berdasarkan Combo Button yang dipilih untuk Status cetak dan Textbox yang di isikan Tahun Pemesanan Pencetakan. Adapun komponen properties pada tampilan Form Cetak Laporan Tahunan, adalah Sebagai berikut:

13. Tampilan Form Backup Database

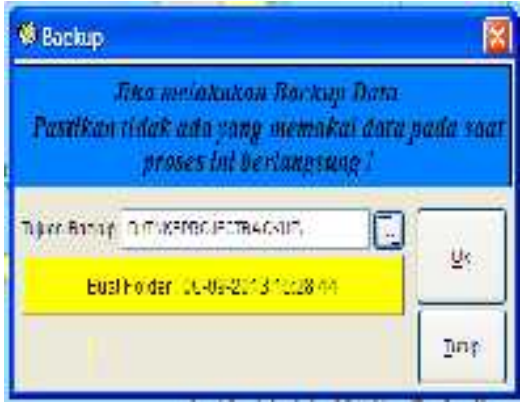

\section{Gambar Tampilan Form Backup Database}

Form ini berfungsi untuk membackup atau membuat cadangan database untuk melindungi data - data yang penting dengan terlebih dahulu menentukan tujuan backup, membuat folder atau ruang khusus Pertanggal dan Jam. Adapun komponen properties pada tampilan Form Backup Database, adalah Sebagai berikut:

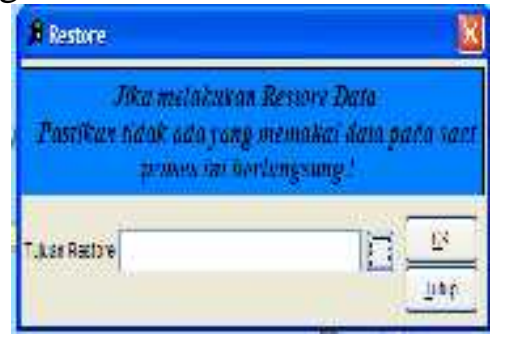

\section{Gambar Tampilan Form Restore Database}

Form ini berfungsi untuk mengembalikan atau mengambil database cadangan/backup untuk perbaikan data - data yang penting dengan terlebih dahulu menentukan tujuan Restore. Adapun komponen properties pada tampilan Form Restore Database, adalah Sebagai berikut: 14. Tampilan Form Re-Index Database

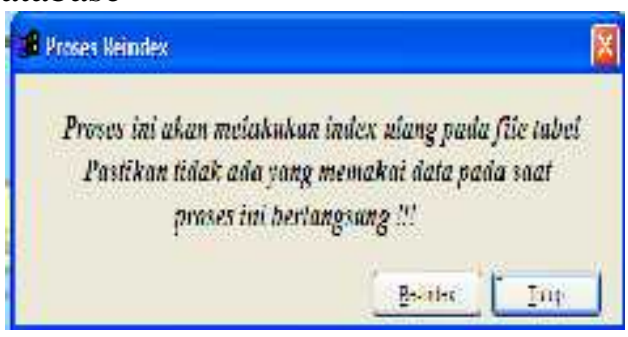




\section{Gambar Tampilan Form Re-Index Database}

Form ini berfungsi untuk index ataupun mengurutkan serta perbaikan database. Adapun komponen properties pada tampilan Form Restore Database, adalah Sebagai berikut:

15. Tampilan Form Pengaturan User (Tambah User)

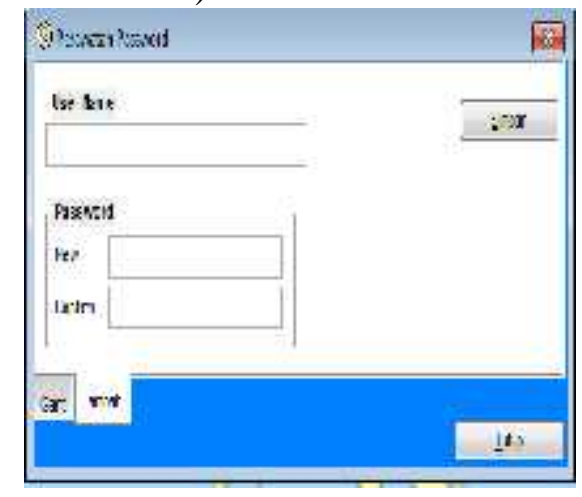

Gambar Tampilan Form Pengaturan User

16. Tampilan Form Pengaturan User (Ganti User)

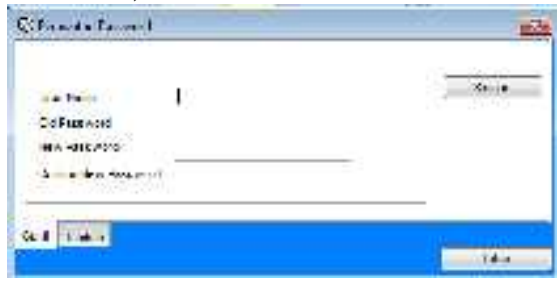

\section{Gambar Tampilan Form Pengaturan} User

17. Tampilan Hasil Cetak Laporan Belum Cetak Tanda Nomor Kendaraan Bermotor

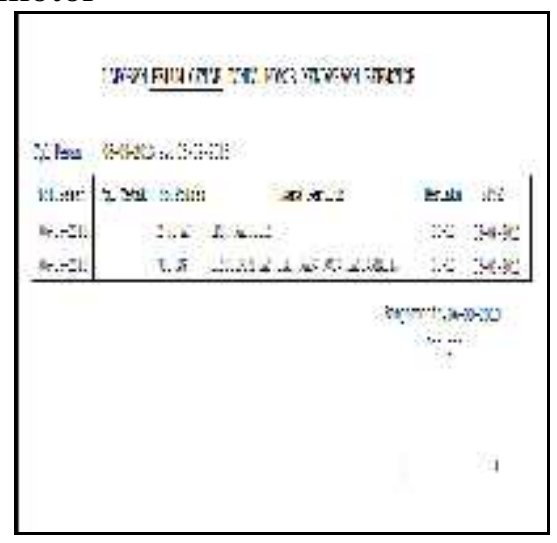

\section{Gambar Tampilan Hasil Cetak Laporan Belum Cetak Tanda Nomor Kendaraan Bermotor}

18. Tampilan Hasil Cetak Laporan Sudah Cetak Tanda Nomor Kendaraan Bermotor

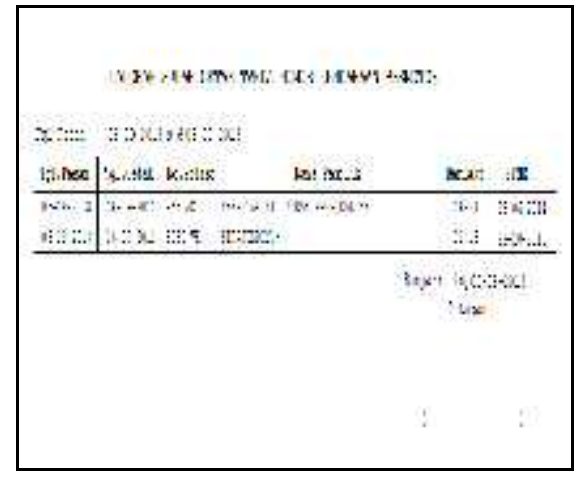

Gambar Tampilan Hasil Cetak Laporan Sudah Cetak Tanda Nomor Kendaraan Bermotor

19. Tampilan Hasil Laporan Staus Cetak

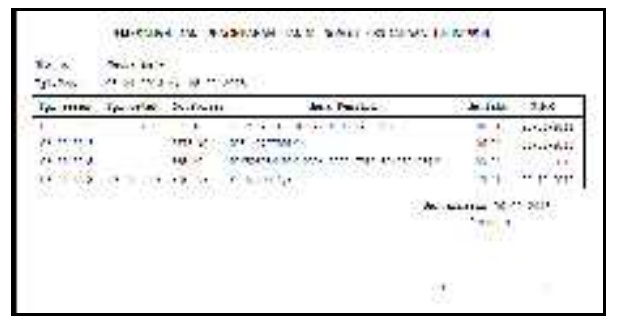

Gambar Tampilan Hasil Cetak Laporan Status Cetak

20. Tampilan Hasil Cetak Laporan Harian

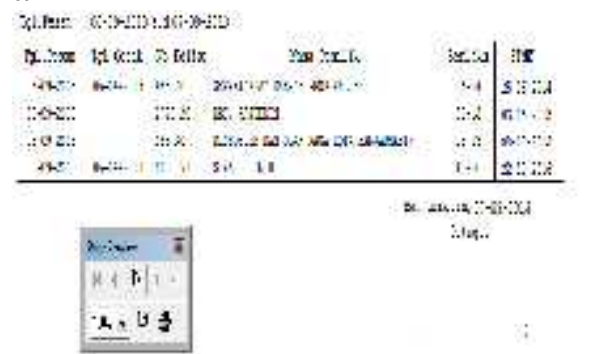

\section{Gambar Tampilan Hasil Cetak Laporan Harian}

21. Tampilan Form Keluar 


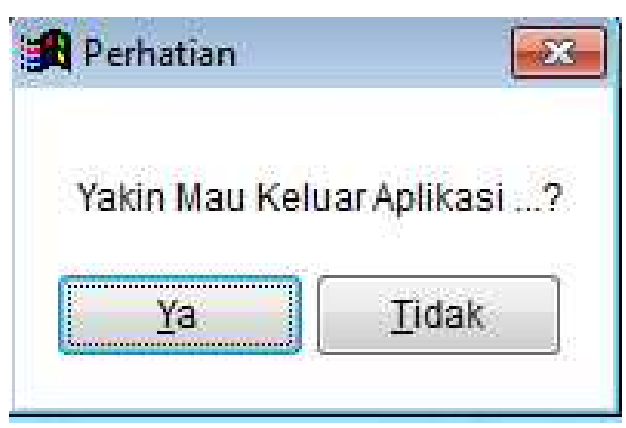

\section{Gambar Tampilan Form Keluar Program}

\section{KESIMPULAN}

Setelah melakukan melakukan Rancangan Aplikasi Layanan Pajak Kendaraan Bermotor Pada Dispenda Banjarmasin maka dapat ditarik kesimpulan serta saran yang nantinya diharapkan berguna dan bermanfaat dalam penerapan Sistem Komputerisasi pada bagian Pemesanan Tanda Nomor Kendaraan Bermotor pada UPPD/Samsat Banjarmasin :

- Rancangan Aplikasi Layanan Pajak Kendaraan Bermotor Pada Dispenda Dapat Membantu Mempermudah Dalam Pengolahan Data Yang Sistematis Dan Terarah, Sehingga Mampu Membantu Kinerja Bagian Pemesanan Tanda Nomor Kendaraan Bermotor Dalam Pencetakan Menjadi Lebih Cepat, Efektif Dan Efisien.

- Rancangan Aplikasi Layanan Pajak Kendaraan Bermotor Pada Dispenda dapat merubah sistem Pemesanan Tanda Nomor Kendaraan Bermotor dari manual menjadi sistem informasi yang terkomputerisasi. Dengan demikian maka pengolahan dan penyimpanan data yang ada menjadi lebih mudah dan akurat.

\section{SARAN}

Diharapkan dengan adanya sistem yang baru , maka Perlu Sumber Daya Manusia yang mempunyai keahlian dalam bidang komputerisasi untuk menunjang berjalannya sistem informasi Pemesanan Tanda Nomor kendaraan Bermotor berbasis komputer.

\section{DAFTAR PUSTAKA}

Andri Kristanto (2003), Perancangan Sistem Informasi dan Aplikasinya, Gava Media, Yogyakarta

Aji Supriyanto (2005), Pengantar Teknologi Informasi, Salemba Infotek, Jakarta

Betha Sidik, Ir (2003), MySQL, Penerbit Informatika, Bandung

Didik Dwi Prasetyo (2003), Belajar Sendiri Administrasi Database Server MySQL, Jakarta

Dwi Budiarti (1999), Sistem Informasi

Manajemen, Mondial, Jakarta

Harianto Kristanto (1994), Konsep dan Perancangan Database, Andi Offset, Yogyakarta

Hery Haryanto, Belajar Sendiri Mengolah Data Melalui Jendela Command dan Menu Utama Visual Foxpro 9.0, www.foxoff.com

Ponco W. Sigit (1999), Analisis dan Perancangan Sistem, Mondial, Jakarta

http://www.artikel2.com/memory.htm,

Di akses pada tanggal 05 September 2017.

http://www.ilmukomputer.com. Di akses pada tanggal 02 Januari 2017.

http://www.gho-

blogs.com/caramembuatkoneksi mysqlodbc, Di akses pada tanggal 13 Februari 2017. 